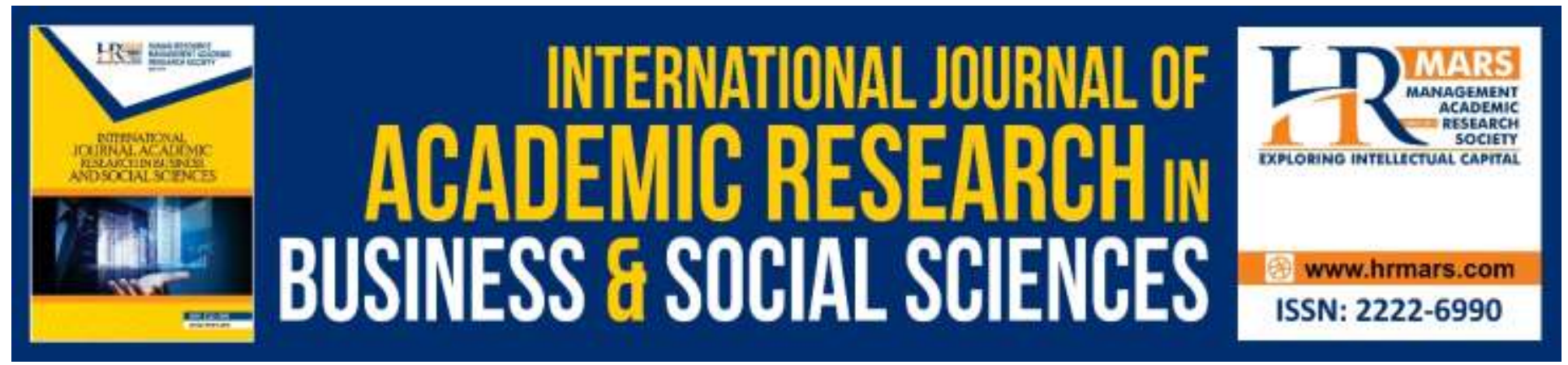

\title{
Authentic Leadership Linking Psychological Empowerment to Follower's Behavior
}

\section{Saira}

To Link this Article: http://dx.doi.org/10.6007/IJARBSS/v9-i11/6529

DOI: $10.6007 /$ IJARBSS/v9-i11/6529

Received: 08 October 2019, Revised: 22 October 2019, Accepted: 30 October 2019

Published Online: 15 November 2019

In-Text Citation: (Saira, 2019)

To Cite this Article: Saira. (2019). Authentic Leadership Linking Psychological Empowerment to Follower's Behavior. International Journal of Academic Research in Business and Social Sciences, 9(11), 61-84.

Copyright: (C) 2019 The Author(s)

Published by Human Resource Management Academic Research Society (www.hrmars.com)

This article is published under the Creative Commons Attribution (CC BY 4.0) license. Anyone may reproduce, distribute, translate and create derivative works of this article (for both commercial and non-commercial purposes), subject to full attribution to the original publication and authors. The full terms of this license may be seen at: http://creativecommons.org/licences/by/4.0/legalcode

Vol. 9, No. 11, 2019, Pg. 61 - 84

Full Terms \& Conditions of access and use can be found at http://hrmars.com/index.php/pages/detail/publication-ethics

\section{Authentic Leadership Linking Psychological Empowerment to Follower's Behavior}




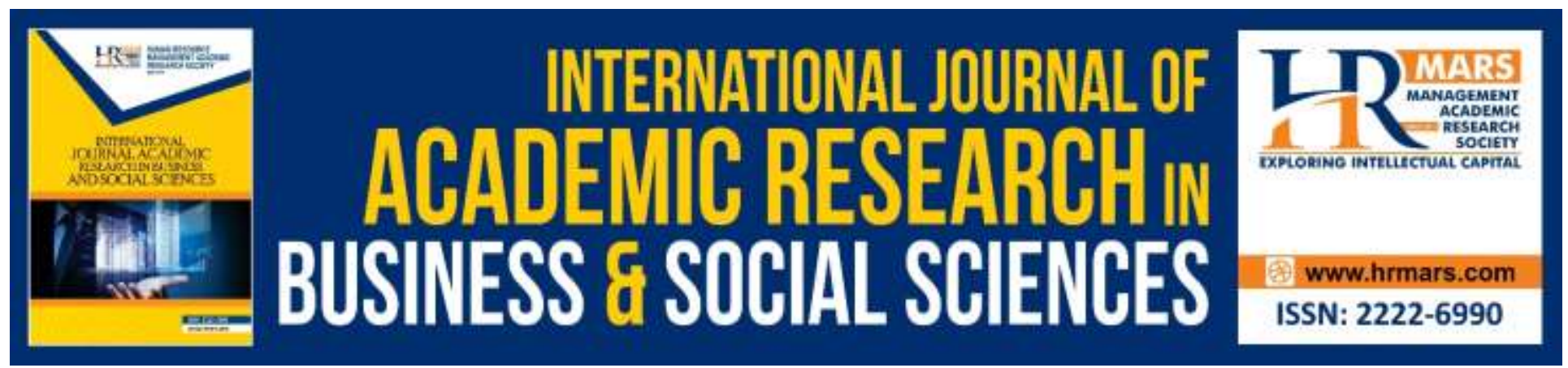

\title{
Saira
}

University of Sargodha, Pakistan

Email: syrah.hassan@gmail.com

\begin{abstract}
This study was conducted to empirically test how follower's organizational citizenship behavior is influenced by authentic leadership mediated by psychological empowerment. This study provides in depth understanding of the relationship between leadership styles and follower's behavior and its strong linkages with psychological empowerment of employees by developing an appropriate research design. Using a quantitative approach, a cross sectional research design was employed to examine the association between Authentic Leadership and organizational citizenship behavior mediated by psychological empowerment. The data was collected from the 200 employees of the textile sector to conduct a research analysis. Reliability analysis, descriptive statistics, factor analysis, Pearson's correlation and regression were applied to test the formulated hypothesis. The results revealed a statically significant relationship among all the variables proposed for this research study. The results of this research study supported the structural model where organizational citizenship behavior is strongly influenced by authentic leadership mediated by psychological empowerment. The result suggested that authentic leadership behavior should be encouraged in all organizational structures to increase the psychological empowerment and organizational citizenship behavior among employees. As far as practical perspective is concerned, it will be helpful for organizations especially in Pakistan where top-down hierarchical control is prevailing, to shift from control to empowerment by implementing authentic leadership styles to foster the organizational citizenship behavior through the linkage of psychological empowerment.
\end{abstract}

Keywords: Authentic Leadership, Psychological Empowerment, Organizational Citizenship Behavior.

\section{Introduction}

In today's competitive work environment, employees with creativity, motivation and outstanding performance are considered a key determinant of organization's success (Cross, Baker, \& Parker, 2003; Walumba \& Lawler, 2003; Pfeffer \& Veiga, 1999). Therefore, it is very critical to utilize the potential of employees for the achievement of organizational goals. Hence, the development of an effective leadership style has been suggested by many researchers (Yukl, 2002; Northouse, 1997).

The concept of authentic leadership has become a significant area of interest for researchers over the last decade. Authentic leadership approach aimed at optimism and meaningfulness is 
required to deal with the societal challenges faced by the organizations (Avolio et al., 2004). Authentic leadership is a process of fostering self-awareness and self-development drawn from psychological capacity. The literature described that followers of authentic leaders feel more psychologically empowered about their work (George, 2003). Authentic leaders influence employee's behaviour positively (Avolio et al., 2004). Psychological empowerment motivates employees by increasing a sense of personal control and work engagement to contribute significantly towards organizational outcomes (Quinn \& Spreitzer, 1997).

In this era, organizations are facing multiple challenges due to complex and uncertain environment. These challenges forced the organizations to be flexible in order to survive in this globalized market. Traditional practices decreased the employee's productivity speed and quality as well. There is a need to shift from control to empowerment in this development phase. In Pakistan, top-down hierarchical control is prevailing in most of the organizations. In these Organizations, employees don't feel themselves to be a part of the organizations as they are not allowed to think, speak or express their opinion. As a result, employee's production rate has been decreased. Therefore, the demand for the employee's psychological empowerment has been generated to increase the productivity and meet the challenges of uncertain environment. However, employee psychological empowerment is insufficient without authentic leadership to cope with the challenges faced by the organizations in globalized market. Authentic leaders Provides an Environment of autonomy to their followers by discovering their talent and empowering them to engage in the tasks accordingly (Clifton \&Harter, 2003; Liden, Wayne, Kraimer \& Sparrowee, 2003).

In this era, organizations are facing continuous environmental changes. Therefore organizations significantly depend on intellectual human capital in order to compete, develop and in this competitive and dynamically changing environment. Employees' behavior played a significant role in the organizational work environment. This dynamically changing environment forced the organizations to invest large number of financial resources on the training, development and retention of employees in order to perform optimal. In this modern era, organizations are defined as learners so employees' OCB is definitely going to affect it positively.

Mostly theoretical research on authentic leadership so far has been done, suggesting exploring the concept of authentic leadership practically (Gardner, Cogliser, Davis, \& Dickens, 2011). Most of researches have described the concept of authentic leadership development (Gardener, Avolio, Luthans, May, \& Walumbwa, 2005; Shamir \& Eilam, 2005; Avolio \& Gardener, 2005) and the relationship between authentic leadership and organizational citizenship behavior (Walumbwa, Peterson, Avolio, \& Hartnel, 2010). However, researchers have not given much importance to authentic leadership concept so far in Pakistan. This study examined the influence of authentic leadership on psychological empowerment of employees in private sector of Pakistan. Further it elaborates the concept of psychological empowerment in association with authentic leadership through literature. This study provides in depth understanding of the authentic leadership and its link with psychological empowerment of employees by developing an appropriate research design.

As far as the relationship between leadership and OCB has been concerned, less research has been done yet. Most of the researches conducted so far have examined the direct effect of 
leadership behaviour and OCB without investigating the role of mediator. Now days it is believed that employee's attitude have direct effect on organizational outcomes (Ladebo, 2005). Employees' work attitude is defined as the thoughts and feelings, employees have about their organization and job. As employees attitude include behavioural component (Ajzen and Fishbein, 1972), therefore it play a significant role in organizational work environment. Therefore, this study is conducted to empirically test how follower's behaviour is influenced by authentic leadership mediated by psychological empowerment.

\section{Research Objectives}

The main objective of this research study is to investigate the relationship between authentic leadership and organizational citizenship behaviour mediated by psychological empowerment. A scientific research methodology is used to empirically test a structural model.

- To investigate the relationship between authentic leadership and organizational citizenship behavior

- To examine the relationship between authentic leadership and organizational citizenship behavior mediated by psychological empowerment

\section{Literature Review}

\section{Authentic leadership}

According to the published literature, Leadership represents the relationship between leaders and followers (Howell \& Shamir, 2005). Therefore, authentic leadership is a process of applying the term authenticity to the leader, followers and the relationship between leader \& followers as well (Gardener et al., 2005). Authentic leadership is an advanced approach of leadership comprised of behavioural transparency (Avolio et al., 2004) and consistency (Eagly, 2005). Authentic leaders know which qualities they should present at what time and how to get acceptance in social cultures change (Goffee \& Jones, 2005).

The literature on authentic leadership revealed four types of authentic leader's behaviour that includes balanced processing, internalized moral perspective, relational transparency, and selfawareness (Walumbwa et al., 2008; Gardener et al., 2005; Ilies, Morgeson, \& Nahrgang, 2005). These four dimensions of authentic leadership have gained a considerable attention of research in the literature of psychology (Walumbwa et al., 2010).

Authentic leaders are more ethical and optimistic that help them to win the trust based relationship of their followers. Authentic Leaders make their followers committed by showing them future oriented approach. Green-leaf (2002) stated that authentic leaders motivate their followers in right direction to make them successful and wiser in their lives. Authentic leaders being a role model make their follower's future leader (Avolio \& Gardner, 2005). Authentic leaders being optimistic and future oriented (Gardner et al., 2005; May, Chan, Hodges, \& Avolio, 2003), focuses particularly on the development of their followers. Authentic leaders are loyal, responsible, broadminded, and honest and believe in equality and social justice like other forms of leadership though distinct in nature (Avolio \& Gardner, 2005; George, 2003; Michie \& Gooty, 
2005). Authentic leaders induce moral and ethical values in their followers and motivate them to long term superior relationship with their customers and shareholders (George, 2003).

Authentic leaders value their integrity and develop authenticity in their followers that lead to their outstanding performance (Gardner et al, 2005). George (2003) stated that authentic leaders accept their mistakes and try to overcome these short comings in the future. Authentic leaders focus on the strengths of the workers instead of weaknesses (Gardner \& Schermerhorn, 2004). Authentic Leaders contributes positively in organizational performance by emerging all the characteristics of authentic leaders, work as a role model and develop trust based relationship with employees.

\section{Authentic Leadership Characteristics \\ Self-Awareness}

Researchers identified self-awareness as the initial point of the authentic leadership (Avolio \& Gardner, 2005; Walumbwa et al., 2008; Avolio et al., 2004; Gardner et al., 2005). Heightened selfawareness is required in authentic leadership (Avolio et al., 2004). Self-awareness means leaders know him fully (May et al., 2003). Self-awareness is a process of knowing One's values, strengths, beliefs, weaknesses (Gardner \& Avolio, 2005). Self-awareness refers to the ability of leader to understand the skills of self and others relevant to emotions and desires (Kernis \& Goldman, 2006). Self-awareness is a person's ability to present oneself authentically in front of other in order to build relationships based on trust (Jourian, 2014). Penger \& Cerne (2014) relates selfawareness to self-reflection.

\section{Balanced Processing}

Balanced processing refers to one's ability of analysing the information objectively before making decisions (Avolio et al., 2009).Balanced processing refers to relevant and non-relevant information about self-esteem incorporating value and belief qualities (Gardener et al., 2005). Jourian (2014) defined the balanced processing as a process of exploring other analysis and perspective in decision making.

\section{Internalized Moral Perspective}

Internalized moral perspective underscores the ethical aspects of decision making (Walumbwa et al., 2008). This dimension refers to a behavior of the leader that is based on moral and ethical standards and not guided by external pressures (Gardener et al., 2005). Jourian (2014) described the internalized moral perspective as a process of self-regulation. Internalized moral perspective refers to one's behaviour based on internal values and moral standard rather than external pressures

\section{Relational Transparency}

This dimension of authentic leadership refers to transparent interaction of leader with followers (Kernis \& Goldman, 2006). Relational transparency refers to a key component involves the 
disclosure of one's emotions and values that enhance the followers trust in leaders (Norman, 2006). Relational transparency refers to share and express the information and feelings openly (Walumbwa et al., 2010).Leaders possessing relational transparency build a trust based relationship with followers by providing secure environment for growth (Macik-Frey et al., 2009).

\section{Authentic Leadership and Psychological Empowerment}

Leaders determine the level of employee's involvement in decision making processes (Walumbwa et al., 2010). Leaders promoting transparent information sharing and inclusive climate, both are attributes of authentic leaders heightened the psychological empowerment of followers (Spreitzer, 1996). Authentic Leadership supports and encourages development of autonomy while creating developmental opportunities for the followers (Deci, Connell, \& Ryan, 1989).

Authentic leaders understand the need of the followers by providing meaning to their work and show trust in them so they can take initiative and work with autonomy (llies et al., 2005). Authentic leaders provide more valuable feedback i.e. a key component of psychological empowerment to the followers through balanced processing and internalized moral perspective (Walumbwa et al., 2010). Authentic leadership motivates followers to share their power and responsibility in the leadership and self-development.

\section{Authentic Leadership and Organizational Citizenship Behaviour}

An extensive research has been done by many researchers to determine the causes and consequences of OCB over the last decade and identified several determinants like organizational characteristics, task characteristics and most importantly leader's behaviour that is relevant to this study (Podsakoff, MacKenzie, Paine, \& Bachrach, 2000). In reviewing literature on OCB, Organ et al. (2006), found that all researchers concluded a significant association between leadership and OCB. This comes from the logic that followers usually enact those behaviours that is emphasized by the behaviour of their leaders (Schneider, Renker, \& Maraun, 2005).

It has been very clear from authentic leadership model that open and supportive work environment behaviours of authentic leaders motivate their followers to engage themselves in organizational helping behaviour even when this is not a part of their job (Avolio \& Gardner, 2005; Brown, Treviño, \& Harrison, 2005). Authentic leaders are perceived to play a significant role in promoting helping behaviour by describing the benefits of helping others and sharing information openly to their followers. Therefore, authentic leaders are expected to promote OCB among their followers.

\section{Research Methodology \\ Structural Model}

The structural model is proposed on the basis of theoretical evidence supported by the literature review. This model is proposed to understand the relationship among all the variables that has been determined to encourage the organizational citizenship behavior. Therefore, the authentic leadership is the most important factors that significantly influence the organizational citizenship behavior in employees. In addition psychological empowerment is a mediating factor that links 
the leadership styles with the follower's behavior. This study focuses on the combination of different variables to understand the relationship among the variables in a comprehensive way.

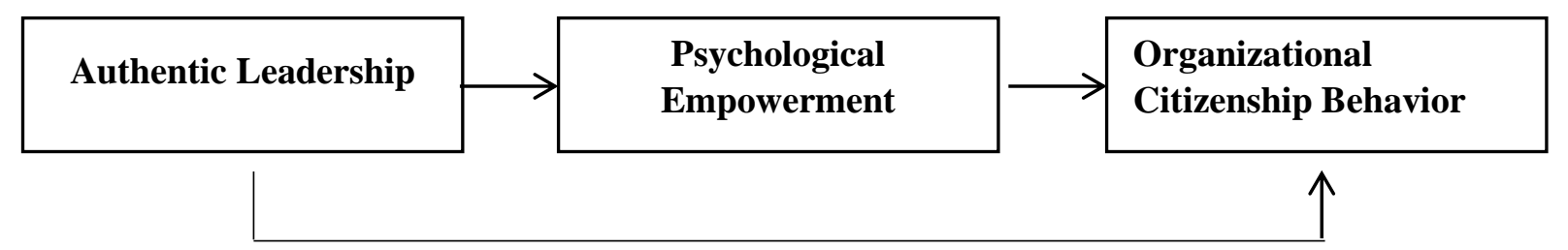

\section{Hypotheses}

Hypothesis 1: A strong positive relationship exists between Authentic Leadership and Organizational Citizenship Behaviour

Hypothesis 2: A strong positive relationship exists between Authentic Leadership and Organizational Citizenship Behaviour mediated by Psychological Empowerment.

Authentic leaders motivate their followers to engage themselves in organizational helping behaviour even when this is not a part of their job (Avolio \& Gardner, 2005; Brown, Treviño, \& Harrison, 2005). Walumba et al, 2010 found that authentic leadership encourages psychological empowerment among employees that creates developmental opportunities for the follower's. The hypothesis 1 and 2 are developed to examine the relationship between Authentic Leadership and Organizational Citizenship Behaviour mediated by Psychological Empowerment.

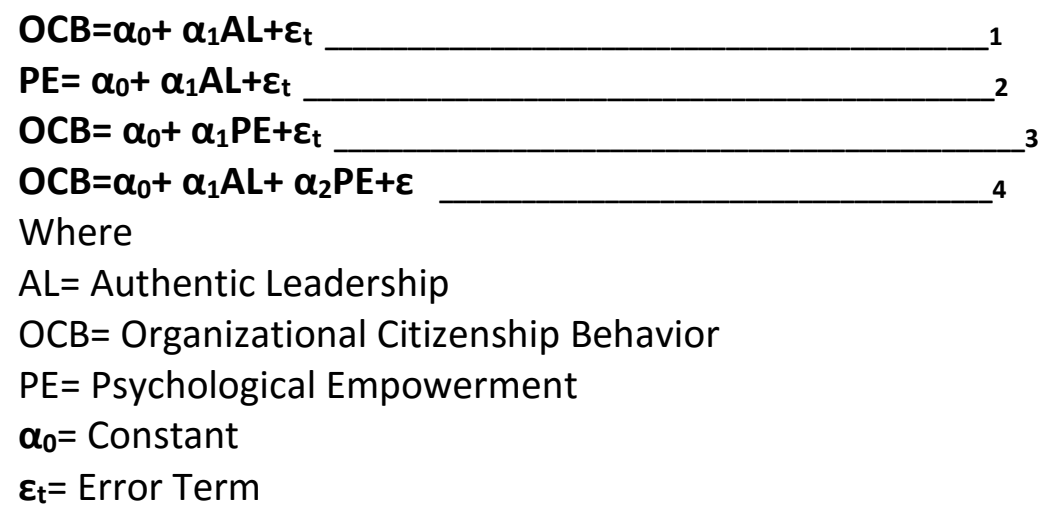

\section{Research Design}

This study used Pearson's correlation to investigate the causal relationship among authentic leadership style, organizational citizenship behavior and psychological empowerment. The correlation design is used to identify the causal relationship between dependent and independent variables in order to identify the direct or indirect effect. This type of research design that is based on correlation has certain limitations that should be taken into account (Babbie \& Mouton, 2006; Babbie \& Mouton, 2001). Therefore, regression was applied on the data to analyze the results revealed by applying correlation. The hypothesis formulated on the basis of structural model is tested with regression in addition to correlation in order to investigate the relationship among variables considered in this study. 


\section{Sampling Technique and Sample Size}

A random sampling technique was used to collect the data from the participants. The participants of the study were the employees of the textile sector. The data was collected from 200 subordinates who were working under a manager. The employees from the textile industry were selected randomly to fill the questionnaire that will help in the completion of thesis. The size of the sample is the major concern in sampling. The sample size of the research should be adequate enough to allow the inference to be made from the findings of the research design about the population.

\section{Data Collection and Measuring Instruments}

The data was collected from the 200 employees of the textile sector to conduct a research analysis in order to understand the relationship between leadership styles and follower's behavior mediated by psychological empowerment. The questionnaire was distributed among the employees with a cover letter contained all the necessary information about the study required by the participants to complete the questionnaire fairly without leaving an unanswered questionnaire. To ensure the confidentiality, participants were not asked any identifying personal question. The response rate was $100 \%$, as all 200 employees returned the filled questionnaire. The questionnaire was properly and satisfactorily filled by the participants that can be used in the study to conduct research analysis.

\section{Authentic Leadership}

The Authentic Leadership Questionnaire designed by Walumbwa et al. (2008), was adopted after some modification to measure the perception of employees regarding the authenticity of their leaders/supervisor using five point likert scale from strongly disagree (5) to strongly agree(1). The authentic leadership questionnaire was comprised of four dimensions i.e. self-awareness and internalized moral perspective, relational transparency and balanced processing each with four items. The four components of transformational leadership were combined to create a composite measure in order to use a single construct of authentic leadership. The highest score marked by the participants indicates that leader or supervisor displays great behavior regarding each component of authentic leadership behavior and the lowest score marked by the participants indicates vice versa.

\section{Psychological Empowerment}

The empowerment questionnaire (MEQ) designed by Spreitzer (1995) comprised of four dimensions including Competence, Meaning, Self-determination and Impact, each with 3-itmes, was adopted after some modification to measure the empowerment level of employees using five point likert scale from strongly disagree (5) to strongly agree(1). High Score of psychological empowerment marked by the participants indicates the level to which employees are psychologically empowered in their job.

\section{Organizational Citizenship Behavior}

Organizational Citizenship Behavior is a modified form of OCB 24- items scale designed by Podsakoff and colleagues (1990; Appendix C), comprised of five dimensions i.e. Altruism, 
Conscientiousness, Civic Virtue, Courtesy and Sportsmanship, using five point likert scale from strongly disagree (5) to strongly agree(1) to measure the strength of employee's behavior. The score indicates the extent to which the participants are engaged in the described behavior Higher OCB score indicates that participants are engaged more in the above described behavior. The participants were assured to keep their answers confidential in order to get the fair response.

\section{Data Analysis}

The statistical techniques used to analyze the collected data and to test the proposed structural model includes reliability analysis, descriptive statistics, correlation, factor analysis and regression. Moreover, Baron and Kenny (1986) approach is used to check the mediation effect between dependent and independent variables. This study applied multiple statistical techniques to test the significance of proposed structural model. Statistical Package for social sciences tool was used to test the hypothesis and analyze the data.

\section{Results of the Study \\ Reliability Analysis}

In Table 4.1, the reliability of all the variables was computed to check the authenticity of the instrument, used to collect the data from the participants to analyse the proposed model for research. The Cronbach's Alpha for all the measures was .815.

\section{Table 4.1 Reliability Analysis}

Reliability Statistics

\begin{tabular}{|r|r|}
\hline $\begin{array}{c}\text { Cronbach's } \\
\text { Alpha }\end{array}$ & N of Items \\
\hline .815 & 48 \\
\hline
\end{tabular}

\section{Descriptive Statistics}

Table 4.2.1 Descriptive Statistics Authentic Leadership

\begin{tabular}{|l|l|l|l|l|l|}
\hline & N & Minimum & Maximum & Mean & Std. Deviation \\
\hline Self_Awareness & 200 & 4.00 & 5.00 & 4.3375 & .27768 \\
Internalized_Moral_Persp & 200 & 4.00 & 5.00 & 4.4062 & .29060 \\
ective & & 4.00 & 5.00 & 4.3913 & .27974 \\
Balanced_Processing & 200 & 4.00 & 5.00 & 4.4125 & .28658 \\
Relational_Transparency & 200 & & & & \\
Valid N (listwise) & 200 & & & & \\
\hline
\end{tabular}

In table 4.2.1, the self-awareness, first subscale of authentic leadership showed mean value 4.33 and S.D=.277 indicated that leader is well aware of his strengths \& weaknesses and willing to accept the feelings about himself. The internalized moral perspective, second subscale of authentic leadership showed mean value 4.40 and $S . D=.290$ indicated that leader action are 
guided by his moral values and are not controlled by the group pressures. The balanced processing, third subscale of authentic leadership showed mean value 4.39 and S.D=.279 indicated that leader seeks the opinion and listen to the ideas of others before making any decision. The relational transparency, fourth subscale of authentic leadership showed mean value 4.41 and $S . D=.286$ indicated that leader share his feelings with others and openly admit his mistakes in front of others. .

Table 4.2.2 Descriptive Statistics Psychological Empowerment

\begin{tabular}{|l|l|l|l|l|l|}
\hline & N & Minimum & Maximum & Mean & Std. Deviation \\
\hline Meaning & 200 & 4.00 & 5.00 & 4.4033 & .31453 \\
Competence & 200 & 4.00 & 5.00 & 4.4067 & .32080 \\
Self_Determination & 200 & 4.00 & 5.00 & 4.3800 & .31176 \\
Impact & 200 & 4.00 & 5.00 & 4.4100 & .32002 \\
Valid N (listwise) & 200 & & & & \\
\hline
\end{tabular}

In, Table 4.2.2, the meaning, first subscale of psychological empowerment showed mean value 4.40 and $S . D=.314$ on a five point likert scale indicated that job activities are very important and meaningful for the participants. The competence, second subscale of psychological empowerment showed mean value 4.40 and $S . D=.320$ indicated that participants have the skills and are capable of doing the job tasks. The self-determination, third subscale of psychological empowerment showed mean value 4.38 and $S . D=.311$ indicated that the participants have the autonomy to determine how to do the job task. The impact, fourth component of psychological empowerment showed mean value 4.41 and $S . D=.320$ indicated that the impact and influence of participants is significant on what happens in the department.

Table: 4.2.3 Descriptive Statistics OCB

\begin{tabular}{|l|l|l|l|l|l|}
\hline & N & Minimum & Maximum & Mean & Std. Deviation \\
\hline Altruism & 200 & 4.00 & 5.00 & 4.3925 & .28632 \\
Sportsmanship & 200 & 4.00 & 5.00 & 4.4000 & .30075 \\
Courtesy & 200 & 4.00 & 5.00 & 4.3925 & .28959 \\
Civic_Virtue & 200 & 4.00 & 5.00 & 4.4075 & .25597 \\
Conscientiousness & 200 & 4.00 & 5.00 & 4.4137 & .28751 \\
Valid N (listwise) & 200 & & & & \\
\hline
\end{tabular}

In Table 4.2.3, the altruism, first subscale of OCB showed mean value 4.39 and $S . D=.286$ on a five point likert scale indicated that participants help their co-workers in their work issues voluntarily. The sportsmanship, second subscale of OCB showed mean value 4.40 and $S . D=.300$ indicated that participants ignore any personal inconvenience to accomplish the tasks at work. The courtesy, 
third subscale of OCB showed mean value 4.39 and S.D $=.289$ indicated that participants are willing to take actions in order to prevent problems for their work fellows. The civic virtue, fourth subscale of OCB showed mean value 4.40 and $S . D=.255$ indicated that participants feel themselves responsible to get involved in the organisational issues. The conscientiousness, fifth subscale of the OCB showed mean value 4.41 and $S . D=.287$ indicated that participants are punctual, show consistency in attendance and properly utilizing the time at work.

\section{Correlation}

Pearson Correlation (2-tailed) was applied on the model to check the relationship among the variables. In table 4.3, Pearson Correlation for the Authentic Leadership with Psychological Empowerment $(r=0.424)$ and Organizational Citizenship Behavior $(r=0.503)$ shows a positive relationship. The entire hypotheses were tested by applying Pearson two tailed correlation on the collected data. The results were supporting the entire hypothesis by showing a significant relationship among all the variables. These findings suggest that authentic leadership empowered the employees psychologically that induced the organizational citizenship behavior and loyalty among employees.

\section{Table 4.3 Correlation}

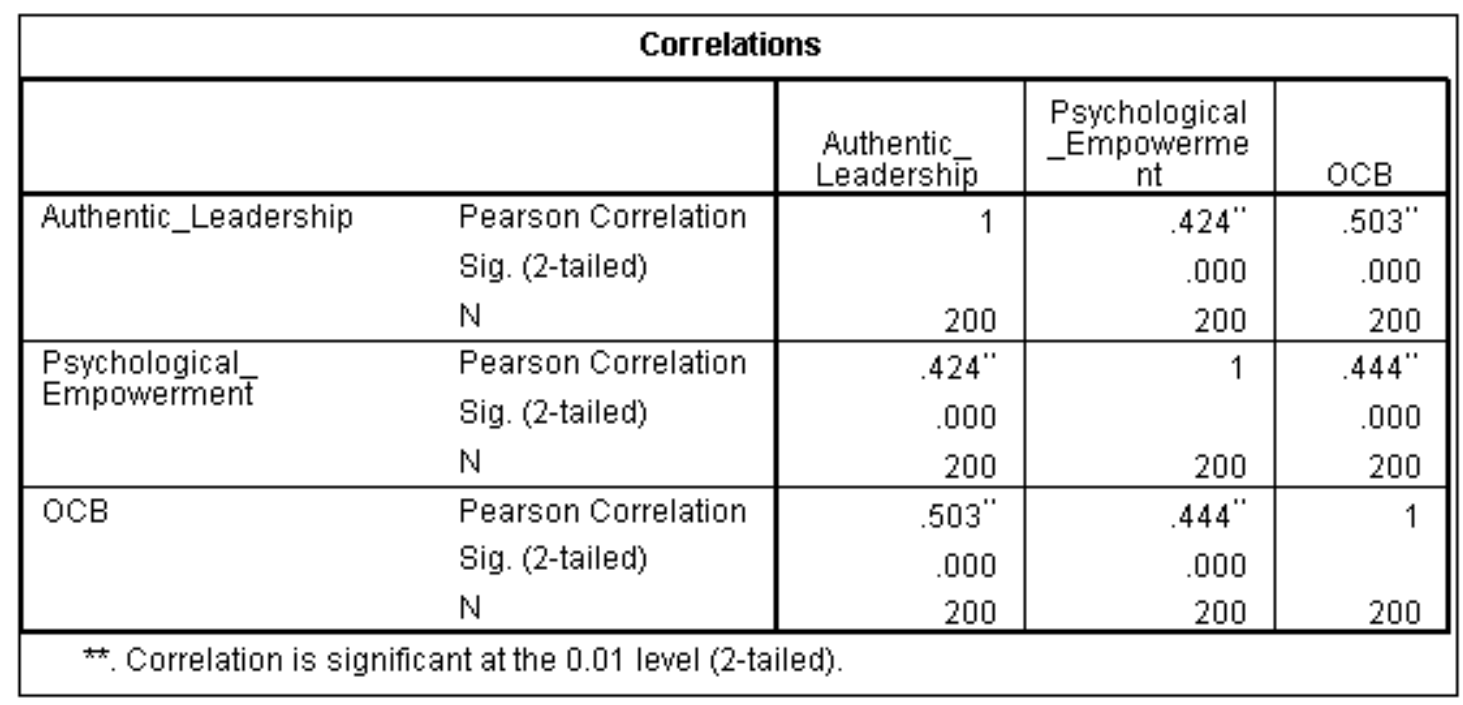

\section{Factor Analysis}

Factor analysis is a statistical technique that is usually used to extract few numbers of variables from the list of large variables. There are multiple methods available to conduct factor analysis but the most commonly used method is principal component analysis. There is multiple assumptions of factor analysis like there should be no multicollinearity and the relationship should be linear.

The total variance table 4.4.1 showed six components of authentic leadership is extracted out of 16 components. The first factor showed the $15.4 \%$ of the total variance, second factor showed $10.20 \%$ of the total variance, the third factor showed $9.53 \%$ of the total variance, forth factor showed $8.09 \%$ of the total variance, the fifth factor showed $7.65 \%$ of the total variance and the 
sixth factor showed $7.60 \%$ of the total variance. These six components out of sixteen components explained $58.49 \%$ of the total variance. The rotated sum of squared loadings distributes the variance of each of the factor over six extracted components. The component one showed $15.4 \%$ variance as compare to others that are $10.20 \%, 9.53 \%, 8.09 \%, 7.65 \%$ and $7.60 \%$ before rotation whereas the first component accounted for $11.21 \%$ as compared to other components that are $10.95 \%, 9.54 \%, 9.42 \%, 9.08 \%$ and $8.27 \%$ variance after rotation.

Table 4.4.1 Total Variance Explained Authentic Leadership

Total Variance Explained

\begin{tabular}{|c|c|c|c|c|c|c|c|c|c|}
\hline \multirow[b]{2}{*}{ Component } & \multicolumn{3}{|c|}{ Initial Eigenvalues } & \multicolumn{3}{|c|}{ Extraction Sums of Squared Loadings } & \multicolumn{3}{|c|}{ Rotation Sums of Squared Loadings } \\
\hline & Total & $\%$ of Variance & Cumulative $\%$ & Total & $\%$ of Variance & Cumulative $\%$ & Total & $\%$ of Variance & Cumulative $\%$ \\
\hline 1 & 2.464 & 15.400 & 15.400 & 2.464 & 15.400 & 15.400 & 1.794 & 11.211 & 11.211 \\
\hline 2 & 1.633 & 10.206 & 25.606 & 1.633 & 10.206 & 25.606 & 1.752 & 10.952 & 22.163 \\
\hline 3 & 1.525 & 9.532 & 35.138 & 1.525 & 9.532 & 35.138 & 1.527 & 9.543 & 31.705 \\
\hline 4 & 1.295 & 8.093 & 43.231 & 1.295 & 8.093 & 43.231 & 1.508 & 9.424 & 41.129 \\
\hline 5 & 1.225 & 7.658 & 50.888 & 1.225 & 7.658 & 50.888 & 1.454 & 9.085 & 50.215 \\
\hline 6 & 1.217 & 7.603 & 58.491 & 1.217 & 7.603 & 58.491 & 1.324 & 8.277 & 58.491 \\
\hline 7 & .966 & 6.040 & 64.531 & & & & & & \\
\hline 8 & .878 & 5.486 & 70.017 & & & & & & \\
\hline 9 & .808 & 5.051 & 75.068 & & & & & & \\
\hline 10 & .788 & 4.926 & 79.993 & & & & & & \\
\hline 11 & .681 & 4.254 & 84.247 & & & & & & \\
\hline 12 & .641 & 4.008 & 88.256 & & & & & & \\
\hline 13 & .562 & 3.515 & 91.771 & & & & & & \\
\hline 14 & .506 & 3.162 & 94.933 & & & & & & \\
\hline 15 & .445 & 2.782 & 97.714 & & & & & & \\
\hline 16 & .366 & 2.286 & 100.000 & & & & & & \\
\hline
\end{tabular}

Extraction Method: Principal Component Analysis.

The total variance table 4.4.2 showed five components of psychological empowerment are extracted out of 12 components. The first factor showed the $16.87 \%$ of the total variance, second factor showed $14.15 \%$ of the total variance, the third factor showed $9.71 \%$ of the total variance, forth factor showed $9.50 \%$ of the total variance and the fifth factor showed $8.84 \%$ of the total variance. These six components out of sixteen components explained $59.09 \%$ of the total variance. The rotated sum of squared loadings distributes the variance of each of the factor over five extracted components. The component one showed $16.87 \%$ variance as compare to others that are $14.15 \%, 9.71 \%, 9.50 \%$ and $8.84 \%$ before rotation whereas the first component accounted for $12.97 \%$ as compared to other components that are $12.93 \%, 12.18 \%, 10.64 \%$ and $10.35 \%$ variance after rotation.

Table 4.4.2 Total Variance Explained Psychological Empowerment 
Total Variance Explained

\begin{tabular}{|c|c|c|c|c|c|c|c|c|c|}
\hline \multirow[b]{2}{*}{ Comnonent } & \multicolumn{3}{|c|}{ |nititial Eigenvalues } & \multicolumn{3}{|c|}{ Extraction Sums of Squared Loadings } & \multicolumn{3}{|c|}{ Rotation Sums of Squared Loadings } \\
\hline & Total & \%of Variance & Cumulative $\%$ & Total & Wof Variance & Cumulative $\%$ & Total & Fofvariance & Cumulative $\%$ \\
\hline 1 & 2.025 & 16.876 & 16.876 & 2.025 & 16.876 & 16.876 & $1.55 ?$ & 12.972 & 12.972 \\
\hline 2 & 1.698 & 14.153 & 31.029 & 1.698 & 14.153 & 31.029 & 1.553 & 12.939 & 25.912 \\
\hline 3 & 1.166 & 9.719 & 40.747 & 1.166 & 9.719 & 40.747 & 1.463 & 12.180 & 38.100 \\
\hline 4 & 1.140 & 9.503 & 50.250 & 1.140 & 9.503 & 50.250 & 1.277 & 10.641 & 48.741 \\
\hline 5 & 1.062 & 8.848 & 59.098 & 1.062 & 8.848 & 59.098 & 1.243 & 10.350 & 59.098 \\
\hline 6 & 986 & 8.220 & 67.318 & & & & & & \\
\hline$?$ & .800 & 6.669 & 73.987 & & & & & & \\
\hline 8 & .762 & 6.353 & 80.339 & & & & & & \\
\hline$g$ & .714 & 5950 & 86.289 & & & & & & \\
\hline 10 & .655 & 5.460 & 91.749 & & & & & & \\
\hline 11 & .542 & 4.518 & 96.267 & & & & & & \\
\hline 12 & .448 & 3.733 & 100.0000 & & & & & & \\
\hline
\end{tabular}

Extraction Method: Principal Component Analysis.

The total variance table 4.4.3 showed six components of organizational citizenship behaviour is extracted out of 16 components. The first factor showed the $16.72 \%$ of the total variance, second factor showed $12.50 \%$ of the total variance, the third factor showed $7.16 \%$ of the total variance, forth factor showed $6.05 \%$ of the total variance, the fifth factor showed $5.90 \%$ of the total variance and the sixth factor showed $5.33 \%$ of the total variance. These six components out of sixteen components explained $53.22 \%$ of the total variance. The rotated sum of squared loadings distributes the variance of each of the factor over six extracted components. The component one showed $16.72 \%$ variance as compare to others that are $12.50 \%, 7.16 \%, 6.05 \%, 5.90 \%$ and $5.33 \%$ before rotation whereas the first component accounted for $10.65 \%$ as compared to other components that are $9.69 \%, 9.66 \%, 8.48 \%, 7.56 \%$ and $7.16 \%$ variance after rotation.

Table 4.4.3 Total Variance Explained Organizational Citizenship Behaviour 
INTERNATIONAL JOURNAL OF ACADEMIC RESEARCH IN BUSINESS AND SOCIAL SCIENCES

Vol. 9, No. 11, November, 2019, E-ISSN: 2222-6990 @ 2019 HRMARS

Total Variance Explained

\begin{tabular}{|c|c|c|c|c|c|c|c|c|c|}
\hline \multirow[b]{2}{*}{ Comnonent } & \multicolumn{3}{|c|}{ Initial Eigenvalues } & \multicolumn{3}{|c|}{ Extraction Sums of Squared Loadings } & \multicolumn{3}{|c|}{ Rotation Sums of Squared Loadings } \\
\hline & Total & $\%$ of Variance & Cumulative $\%$ & Total & \%of Variance & Cumulative $\%$ & Total & $\%$ of Variance & Cumulative $\%$ \\
\hline 1 & 3.344 & 16.722 & 16.722 & 3.344 & 16.722 & 16.722 & 2.131 & 10.657 & 10.657 \\
\hline 2 & 2.410 & 12.050 & 28.772 & 2.410 & 12.050 & 28.772 & 1.939 & 9.694 & 20.351 \\
\hline 3 & 1.433 & 7.165 & 35.937 & 1.433 & 7.165 & 35.937 & 1.932 & 9.662 & 30.013 \\
\hline 4 & 1.210 & 6.050 & 41.986 & 1.210 & 6.050 & 41.986 & 1.698 & 8.489 & 38.502 \\
\hline 5 & 1.182 & 5.908 & 47.895 & 1.182 & 5.908 & 47.895 & 1.513 & 7.567 & 46.069 \\
\hline 6 & 1.067 & 5.335 & 53.229 & 1.067 & 5.335 & 53.229 & 1.432 & 7.161 & 53.229 \\
\hline 7 & .967 & 4.833 & 58.063 & & & & & & \\
\hline 8 & .948 & 4.741 & 62.803 & & & & & & \\
\hline 9 & .886 & 4.428 & 67.231 & & & & & & \\
\hline 10 & .810 & 4.048 & 71.280 & & & & & & \\
\hline 11 & .740 & 3.699 & 74.978 & & & & & & \\
\hline 12 & .719 & 3.593 & 78.571 & & & & & & \\
\hline 13 & .656 & 3.281 & 81.852 & & & & & & \\
\hline 14 & .632 & 3.161 & 85.013 & & & & & & \\
\hline 15 & .590 & 2.949 & 87.962 & & & & & & \\
\hline 16 & .560 & 2.800 & 90.762 & & & & & & \\
\hline 17 & .520 & 2.601 & 93.363 & & & & & & \\
\hline 18 & .473 & 2.364 & 95.726 & & & & & & \\
\hline 19 & .437 & 2.187 & 97.914 & & & & & & \\
\hline 20 & .417 & 2.086 & 100.000 & & & & & & \\
\hline
\end{tabular}

Extraction Method: Principal Component Analysis.

\section{Regression Analysis}

Table 4.5.1 Model Summary

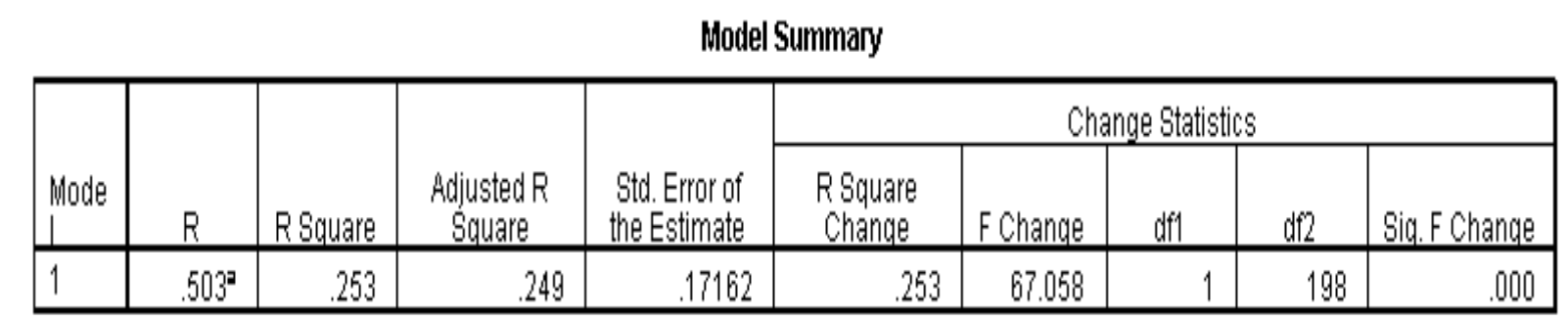

a. Predictors: (Constant), Authentic_Leadership

In table 4.5.1, the value of Coefficient of determination $\left(R^{2}\right)$ is 0.253 that indicates the $25 \%$ variation in organizational citizenship behavior is due to proposed model.

Table 4.5.2 ANOVA $^{b}$ 
ANONA $^{\text {b }}$

\begin{tabular}{|ll|r|r|r|r|c|}
\hline Madel & & \multicolumn{1}{c|}{$\begin{array}{c}\text { Sum of } \\
\text { Squares }\end{array}$} & \multicolumn{1}{c|}{ df } & Mean Square & F & Sig. \\
\hline 1 & Regression & 1.975 & 1 & 1.975 & 67.058 & $.000^{=}$ \\
& Residual & 5.832 & 198 & .029 & & \\
& Total & 7.807 & 199 & & & \\
\hline
\end{tabular}

a. Predictors: (Constant), Authentic_Leadership

b. Dependent Variable: $\mathrm{OCB}$

In table 4.5.2 the significant value of F Statistic in ANOVA table is less than 0.05 shows that the model is statistically significant.

Table 4.5.3 Coefficients ${ }^{\mathrm{a}}$

\begin{tabular}{|c|c|c|c|c|c|c|}
\hline \multirow{2}{*}{\multicolumn{2}{|c|}{ Model }} & \multicolumn{2}{|c|}{$\begin{array}{c}\text { Unstandardized } \\
\text { Coefficients }\end{array}$} & $\begin{array}{l}\text { Standardized } \\
\text { Coefficients }\end{array}$ & \multirow[b]{2}{*}{$\mathrm{t}$} & \multirow[b]{2}{*}{ Sig. } \\
\hline & & ß & Std. Error & Beta & & \\
\hline \multirow[t]{2}{*}{1} & (Constant) & 2.091 & .282 & & 7.403 & .000 \\
\hline & $\begin{array}{l}\text { Authentic_Leader } \\
\text { ship }\end{array}$ & .527 & .064 & .503 & 8.189 & .000 \\
\hline
\end{tabular}

a. Dependent Variable: OCB

The coefficient table 4.5.3 shows that Authentic Leadership is significant as it significant value is less than 0.05 . The beta value of authentic leadership in table 4.5 .3 shows the one unit increase in authentic leadership raise the organizational citizenship behavior by 50 units. The higher $t$ value with a significant value less than 0.05 shows a strong influence of authentic leadership on organizational citizenship behavior. This table clearly indicates that there is a strong and positive relationship between Authentic Leadership and Organizational Citizenship Behavior.

Table 4.5.4 Model Summary

\begin{tabular}{|l|r|r|r|r|}
\hline \multicolumn{1}{|c}{ Model Summary } \\
\hline Model & \multicolumn{1}{c|}{ R } & R Square & $\begin{array}{c}\text { Adjusted R } \\
\text { Square }\end{array}$ & $\begin{array}{c}\text { Std. Error of } \\
\text { the Estimate }\end{array}$ \\
\hline 1 & $.668^{\mathrm{a}}$ & .424 & .416 & .17834 \\
\hline
\end{tabular}

a. Predictors: (Constant), Authentic_Leadership

In table 4.5.4, the value of Coefficient of determination $\left(R^{2}\right)$ is 0.424 that indicates the $42 \%$ variation in psychological empowerment is due to proposed model.

Table 4.5.5 ANOVA ${ }^{b}$ 
INTERNATIONAL JOURNAL OF ACADEMIC RESEARCH IN BUSINESS AND SOCIAL SCIENCES

Vol. 9, No. 11, November, 2019, E-ISSN: 2222-6990 ㄷ 2019 HRMARS

ANOVA ${ }^{b}$

\begin{tabular}{|ll|r|r|r|r|r|}
\hline \multicolumn{1}{|c|}{} & \multicolumn{1}{|c|}{$\begin{array}{c}\text { Sum of } \\
\text { Squdel }\end{array}$} & & df & Mean Square & \multicolumn{1}{c|}{ F } & Sig. \\
\hline 1 & Regression & 1.383 & 1 & 1.383 & 43.500 & $.000=$ \\
& Residual & 6.297 & 198 & .032 & & \\
& Total & 7.681 & 199 & & & \\
\hline
\end{tabular}

a. Predictors: (Constant), Authentic_Leadership

b. Dependent Variable: Psychological_Empowerment

In table 4.5.5, the significant value of F Statistic in ANOVA table is less than 0.05 shows that the model is statistically significant.

Table 4.5.6 Coefficients ${ }^{a}$

Coefficients ${ }^{3}$

\begin{tabular}{|c|c|c|c|c|c|c|}
\hline \multirow[b]{2}{*}{ Madel } & & \multicolumn{2}{|c|}{ Unstandardized Coefficients } & $\begin{array}{l}\text { Standardized } \\
\text { Coefficients }\end{array}$ & \multirow[b]{2}{*}{$\mathrm{t}$} & \multirow[b]{2}{*}{ Sig. } \\
\hline & & $\mathrm{B}$ & Std. Error & Beta & & \\
\hline 1 & (Constant) & 2.466 & .293 & & 8.404 & .000 \\
\hline & Authentic_Leadership & .441 & .067 & .424 & 6.595 & .000 \\
\hline
\end{tabular}

a. Dependent Variable: Psychological_Empowerment

The coefficient table 4.5.6 shows the significance of Authentic Leadership as its value is less than 0.05. The beta value of authentic leadership in the table 4.5.6 shows the one unit increase in authentic leadership raise the psychological empowerment by .42 units. The higher $t$ value with a significant value less than 0.05 shows a strong influence of authentic leadership on psychological empowerment. This table clearly indicates that there is a strong and positive relationship between psychological empowerment and Authentic Leadership.

Table 4.5.7 Model Summary

Model Summary

\begin{tabular}{|l|r|r|r|r|}
\hline Model & R & R Square & \multicolumn{1}{c|}{$\begin{array}{c}\text { Adjusted R } \\
\text { Square }\end{array}$} & $\begin{array}{c}\text { Std. Error of } \\
\text { the Estimate }\end{array}$ \\
\hline 1 & $.444^{\mathrm{a}}$ & .198 & .193 & .17788 \\
\hline
\end{tabular}

a. Predictors: (Constant), Psychological_Empowerment

In table 4.5.7, the value of Coefficient of determination $\left(R^{2}\right)$ is 0.424 that indicates the $42 \%$ variation in organizational citizenship behavior is due to proposed model. 
ANONA $^{\text {b }}$

\begin{tabular}{|ll|r|r|r|r|c|}
\hline Madel & & \multicolumn{1}{c|}{$\begin{array}{c}\text { Sum of } \\
\text { Squares }\end{array}$} & \multicolumn{1}{c|}{ df } & Mean Square & \multicolumn{1}{c|}{ F } & Sig. \\
\hline 1 & Regression & 1.542 & 1 & 1.542 & 48.741 & $.000^{=}$ \\
& Residual & 6.265 & 198 & .032 & & \\
& Total & 7.807 & 199 & & & \\
\hline
\end{tabular}

a. Predictors: (Constant), Psychological_Empowerment

b. Dependent Variable: $\mathrm{OCB}$

In table 4.5.8, the significant value of F Statistic in ANOVA table is less than 0.05 shows that the model is statistically significant.

Table 4.5.9 Coefficients ${ }^{a}$

Coefficients $^{\mathrm{s}}$

\begin{tabular}{|c|c|c|c|c|c|c|}
\hline \multirow[b]{2}{*}{ Madel } & & \multicolumn{2}{|c|}{ Unstandardized Coefficients } & $\begin{array}{l}\text { Standardized } \\
\text { Coefficients }\end{array}$ & \multirow[b]{2}{*}{$t$} & \multirow[b]{2}{*}{ Siq. } \\
\hline & & $\mathrm{B}$ & Std. Error & Beta & & \\
\hline 1 & (Constant) & 2.430 & .283 & & 8.595 & .000 \\
\hline & $\begin{array}{l}\text { Psychological } \\
\text { Empowerment }\end{array}$ & .448 & .064 & .444 & 6.981 & .000 \\
\hline
\end{tabular}

a. Dependent Variable: OCB

The coefficient table 4.5.9 shows the significance of psychological empowerment as its value is less than 0.05 . The beta value of psychological empowerment in the table 4.5 .9 shows the one unit increase in psychological empowerment raise the authentic leadership by .44 units. The higher $t$ value with a significant value less than 0.05 shows a strong influence of psychological empowerment on authentic leadership. This table clearly indicates that there is a strong and positive relationship between psychological empowerment and organizational citizenship behavior.

Table 4.5.10 Model Summary

\begin{tabular}{|c|c|c|c|c|c|c|c|c|c|}
\hline \multicolumn{10}{|c|}{ Model Summary } \\
\hline \multirow[b]{2}{*}{$\perp^{\text {Mode }}$} & \multirow[b]{2}{*}{$\mathrm{R}$} & \multirow[b]{2}{*}{ R Square } & \multirow[b]{2}{*}{$\begin{array}{c}\text { Adjusted R } \\
\text { Square } \\
\end{array}$} & \multirow[b]{2}{*}{$\begin{array}{l}\text { Std. Error of } \\
\text { the Estimate }\end{array}$} & \multicolumn{5}{|c|}{ Change Statistics } \\
\hline & & & & & $\begin{array}{l}\text { R Square } \\
\text { Change }\end{array}$ & F Change & df1 & $\mathrm{d} f 2$ & Sig. F Change \\
\hline 1 & $.564^{2}$ & .318 & .311 & .16439 & .318 & 45.942 & 2 & 197 & .000 \\
\hline
\end{tabular}

a. Predictors: (Constant), Psychological_Empowerment, Authentic_Leadership

In table 4.5.10, the value of Coefficient of determination $\left(R^{2}\right)$ is 0.318 that indicates the $31 \%$ variation in organizational citizenship behavior is due to proposed model.

Table 4.5.11 ANOVA ${ }^{b}$ 
ANOVA $^{\text {b }}$

\begin{tabular}{|ll|r|r|r|r|r|}
\hline Madel & & \multicolumn{1}{c|}{$\begin{array}{c}\text { Sum of } \\
\text { Squares }\end{array}$} & \multicolumn{1}{c|}{ df } & Mean Square & F & Sig. \\
\hline 1 & Regression & 2.483 & 2 & 1.242 & 45.942 & $.000^{=}$ \\
& Residual & 5.324 & 197 & .027 & & \\
& Total & 7.807 & 199 & & & \\
\hline
\end{tabular}

a. Predictors: (Constant), Psychological_Empowerment, Authentic_Leadership

b. Dependent Variable: $\mathrm{OCB}$

In table 4.5.11, the significant value of F Statistic in ANOVA table is less than 0.05 shows that the model is statistically significant.

Table 4.5.12 Coefficients ${ }^{a}$

\section{Coefficients $^{\mathrm{a}}$}

\begin{tabular}{|c|c|c|c|c|c|c|}
\hline \multirow{2}{*}{\multicolumn{2}{|c|}{ Model }} & \multicolumn{2}{|c|}{$\begin{array}{l}\text { Unstandardized } \\
\text { Coefficients }\end{array}$} & \multirow{2}{*}{$\begin{array}{c}\begin{array}{c}\text { Standardized } \\
\text { Coefficients }\end{array} \\
\text { Beta }\end{array}$} & \multirow[b]{2}{*}{$\mathrm{T}$} & \multirow[b]{2}{*}{ Sig. } \\
\hline & & $\beta$ & Std. Error & & & \\
\hline \multirow[t]{3}{*}{1} & (Constant) & 1.390 & .315 & & 4.412 & .000 \\
\hline & Authentic_Leadership & .401 & .068 & .383 & 5.901 & .000 \\
\hline & $\begin{array}{l}\text { Psychological_Empower } \\
\text { ment }\end{array}$ & .284 & .066 & .282 & 4.336 & .000 \\
\hline
\end{tabular}

a. Dependent Variable: OCB

The coefficient table 4.5.12 shows that Authentic Leadership and psychological empowerment are significant as their significant values are less than 0.05 . The beta value of psychological empowerment in the table 4.5.12 shows the one unit increase in psychological empowerment increase the organizational citizenship behavior by 28 units. The beta value of authentic leadership in the table 4.5.12 shows the one unit increase in authentic leadership increase the organizational citizenship behavior by 28 units. The higher $t$ value with a significant value less than 0.05 shows a strong influence of authentic leadership and psychological empowerment on organizational citizenship behavior. This table clearly indicates that there is a strong and positive relationship between Authentic Leadership, Psychological Empowerment and Organizational Citizenship Behavior.

Hypothesis 1 was formulated to examine the relationship between authentic leadership and organizational citizenship behaviour. The table 4.4.1 showed a positive correlation between authentic leadership and organizational citizenship behaviour i.e. ( $r=.503$ ). Afterwards, the regression was applied to test the hypothesis. The significance value is less than 0.05 that shows the fitness of the model. The beta value in table 4.5 .3 shows the one unit increase in authentic leadership raise the organizational citizenship behaviour by .50 units. Therefore, the results 
clearly indicated a strong and positive relationship between authentic leadership and organizational citizenship behaviour.

The result of the hypothesis clearly indicates that authentic leaders enhance organizational citizenship behaviour among employees that is consistent with the previous researchers (Avolio \& Gardner, 2005; Brown, Treviño, \& Harrison, 2005). Authentic leaders promote helping behaviour in their employees by describing them the benefits of sharing information and helping others. Authentic leaders motivate their followers to help other employees who are facing difficulties in their job. Therefore, authentic leaders tend to promote organizational citizenship behaviour among employees.

Hypothesis 2 was formulated to examine the relationship between Authentic Leadership and Organizational Citizenship Behaviour mediated by Psychological Empowerment. The correlation showed a positive relationship between authentic leadership and psychological empowerment i.e. $(r=.424)$ in table 4.4.1. Moreover, the regression was applied to test the hypothesis. The significance value is less than 0.05 that shows the fitness of the model. The beta value in the table 4.5.12 shows the one unit increase in psychological empowerment increase the organizational citizenship behavior by .28 units and one unit increase in authentic leadership increase the organizational citizenship behavior by .38 units. Therefore, the results clearly indicated a strong and positive relationship between transformational leadership and Organizational Citizenship Behaviour partially mediated by Psychological Empowerment.

The result of this hypothesis clearly indicates that authentic leaders enhance the psychological empowerment among employees that is consistent with previous researcher (Walumbwa et al., 2010). The findings of this hypothesis clearly indicate that authentic leaders develop maximum potential in their followers and empower them to enhance organizational citizenship behaviour.

\section{Conclusions, Recommendations and Future Research Conclusion}

The objective of this study was to examine the relationship between authentic leadership and organizational citizenship behavior mediated by psychological empowerment. The results revealed a statically significant relationship among all the variables proposed for this research study. The present study concluded that the organizations should develop authentic leadership style at the supervisor positions to encourage the psychological empowered behavior among employees. The psychologically empowered employees display the organizational citizenship behavior that reduces the turnover intention among employees.

This study focused to explain the link between authentic leadership and psychological empowerment of employees. The results of the study are consistent with theoretical assumptions. Authentic leaders' support their follower's to feel psychologically empowered. Followers who work under the supervision of authentic leaders feel themselves psychologically empowered that in turn increase their work engagement and job satisfaction (Penger \& Cerne, 2014). The results of this study are consistent with Walumbwa et al, 2010. This study revealed that authentic leaders influence the psychological empowerment of employees positively. The outcome of this research is that psychologically empowered employees are more creative than 
employees who are not psychologically empowered and that can only be led by authentic leaders (Rego et al. 2012).

Moreover, the results clearly indicated a strong relationship between psychological empowerment and organizational citizenship behavior. Organizational Citizenship behavior plays a significant role in the productivity and success of the organization. The organizational citizenship behavior positively contributes to the organizational performance acknowledged by many researchers (Castro et al., 2004; Podsakoff \& Mackenzie, 1997; Euwema \& Emmerik, 2007). Therefore, it is clearly stated that leader's behavior towards subordinates can create organizational citizenship behavior and psychological empowerment among employees. Higher level of psychological empowerment leads to higher level of organizational citizenship behavior. Therefore, it is important for the organization to psychologically empower the employees in order to bring a positive change in the behavior of their valued employees. It is important for the organization to incorporate authentic leadership behavior in their supervisors during their training to achieve the desired results (Humphrey, 2012).

The managers are required to be more caring about their followers and emphasize high moral and ethical standards to understand their followers in the working relationships. When managers identify their follower's strength and its contribution towards organizational goals, this will lead to psychological empowerment resulting in organizational citizenship behavior. This will help the employees to utilize their strengths in performing their job tasks lead to achieve the desired outcomes. This will encourage the employees to take more responsibility with a greater sense of psychological empowerment especially when they see the transparent and balanced behavior of their in decision making.

Authentic leadership by exhibiting transparent behavior complements other styles of leadership where the followers trust their leaders of transparent and fair decision making. The followers believe that authentic leaders are well aware of their employee's performance and their contribution towards the accomplishment of organizational goals. Authentic Leaders engage their employees more in their job tasks by displaying high moral and ethical standards. The results clearly suggested that employees feel themselves more psychologically empowered when their leaders are exhibiting authentic leadership styles. The psychologically empowered employees are engaged more in organizational citizenship behavior by involving themselves more in work beyond their job description.

The findings of the study indicated that psychological empowerment as a mediating factor support the relationship between leadership styles and followers behavior. The psychological empowered employees feel themselves free from upper management pressure and thus are more engaged in their work (Schaufeli \& Bakker, 2004) that leads to the productivity of the organization. The results of the study clearly described the relationship between leadership styles and followers behavior mediated by psychological empowerment. The positive influence of authentic leadership on organizational citizenship behavior is aligned with previous studies (Walumbwa et al., 2008).

Walumbwa et al. (2010 research study showed a positive influence of authentic leadership style on psychological empowerment and organizational citizenship behavior of employees. Moreover, this research study indicated the authentic leadership style is a suitable style to 
enhance the organizational citizenship behavior among employees. Therefore, the managers should develop authentic leadership style in order to enhance organizational citizenship behavior among employees by psychologically empowering them. The managers would be able to achieve the desired outcomes from the employees by developing the skills of authentic leadership style. This research study strongly suggests the organizations to develop the authentic leadership styles at all levels of organization structure.

\section{Practical Implications}

This study has significant practical implications as it is helpful for leaders to emphasize the characteristics of authentic leadership to enhance psychological empowerment of employees that in turn increase employee's work engagement (Walumbwa et al., 2010). This is very important particularly in gaining competitive advantage in global market (Harter, Schmidt, \& Hayes, 2002). Authentic leaders by psychologically empowering the employees can increase their follower's work engagement (Walumbwa et al., 2010).

This study suggests that leaders should have discussion with individual employee about his strengths and how his strengths can make a difference in his work that will help in building a transparent relationship between leader and employee that will lead to follower's positive outcomes. An authentic leader is one who encourages his employee to be psychologically empowered and open in addition to be engaged with his work. This way, leaders help employees in clarifying and changing their roles according to their strengths to achieve organizational outcomes.

This study showed significant practical implications for the organizations. The findings of the study showed that it is important for the managers to emphasize balanced processing, transparency, high ethical standards to enhance organizational citizenship behavior among employees. To enhance organizational citizenship behavior is being recognized as a global competitive advantage (Harter et al., 2002). Therefore authentic leadership style exhibited by the managers seems beneficial to enhance the organizational citizenship behavior among employees.

\section{Limitations and Future Research}

This study was primarily based on cross sectional design. Future research based on longitudinal research design can be conducted to examine how authentic leaders build relationships with their followers in terms of its impact on their work outcomes and engagement (Walumbwa et al., 2010).

Second limitation is this study applied descriptive statistics, factor analysis, correlation, regression and Barron and Kenny approach whereas other methods may have significant influence on findings of the research. Moreover, other researchers may address this issue by approaching qualitative and quantitative method simultaneously in order to generalize the results of the study.

Third, this study approached the authentic leadership style while future research can be conducted by considering other leadership styles like charismatic leadership, empowering and ethical leadership (Walumbwa et al., 2010). 


\section{References}

Avolio, B. J., \& Gardner, W. L. (2005). Authentic leadership development: Getting to the root of positive forms of leadership. The leadership quarterly, 16(3), 315-338.

Avolio, B. J., Zhu, W., Koh, W., \& Bhatia, P. (2004). Transformational leadership and organizational commitment: Mediating role of psychological empowerment and moderating role of structural distance. Journal of Organizational Behavior: The International Journal of Industrial, Occupational and Organizational Psychology and Behavior, 25(8), 951-968.

Mouton, J., \& Babbie, E. (2001). The practice of social research. Cape Town: Wadsworth Publishing Company, 871-890.

Babbie, E., \& Mouton, J. (2006). The Practice of Social Research. Cape Town: Oxford University Press Southern Africa.

Brown, M. E., Treviño, L. K., \& Harrison, D. A. (2005). Ethical leadership: A social learning perspective for construct development and testing. Organizational behavior and human decision processes, 97(2), 117-134.

Castro, B. C., Armario, M. E., \& Ruiz, M. D. (2004). The influence of employee organizational citizenship behavior on customer loyalty. International journal of Service industry management, 15(1), 27-53.

Clifton, D. O., \& Harter, J. K. (2003). Investing in strengths. Positive organizational scholarship: Foundations of a new discipline, 111-121.

Cross, R., Baker, W., \& Parker, A. (2003). What creates energy in organizations?. MIT Sloan Management Review, 44(4), 51.

Deci, E. L., Connell, J. P., \& Ryan, R. M. (1989). Self-determination in a work organization. Journal of applied psychology, 74(4), 580.Eagly, A. H. (2005). Achieving relational authenticity in leadership: Does gender matter. The Leadership Quarterly, 16(3), 459-474.

Euwema, M. C., \& Emmerik, V. I. H. (2007). Intercultural competencies and conglomerated conflict behaviors in intercultural conflicts. International Journal of Intercultural Relations, 31(4), 427-441.

Ajzen, I., \& Fishbein, M. (1977). Attitude-behavior relations: A theoretical analysis and review of empirical research. Psychological bulletin, 84(5), 888.

Gardner, W. L., Avolio, B. J., Luthans, F., May, D. R., \& Walumbwa, F. (2005). "Can you see the real me?" A self-based model of authentic leader and follower development. The Leadership Quarterly, 16(3), 343-372.

Gardner, W. L., Cogliser, C. C., Davis, K. M., \& Dickens, M. P. (2011). Authentic leadership: A review of the literature and research agenda. The leadership quarterly, 22(6), 1120-1145.

Gardner, W. L., \& Schermerhorn, J. R. (2004). Unleashing individual potential. Organizational dynamics, 3(33), 270-281.

George, B. (2003). Authentic leadership: Rediscovering the secrets to creating lasting value. John Wiley \& Sons.

Goffee, R., \& Jones, G. (2005). Managing authenticity. harvard business review, 83(12), 85-94.

Greenleaf, R. K. (2002). Servant leadership: A journey into the nature of legitimate power and greatness. Paulist Press. 
Harter, J. K., Schmidt, F. L., \& Hayes, T. L. (2002). Business-unit-level relationship between employee satisfaction, employee engagement, and business outcomes: A meta-analysis. Journal of applied psychology, 87(2), 268.

Humphrey, A. (2012). Transformational leadership and organizational citizenship behaviors: The role of organizational identification. The Psychologist-Manager Journal, 15(4), 247-268.

Howell, J. M., \& Shamir, B. (2005). The role of followers in the charismatic leadership process: Relationships and their consequences. Academy of management review, 30(1), 96-112.

Ilies, R., Morgeson, F. P., \& Nahrgang, J. D. (2005). Authentic leadership and eudaemonic wellbeing: Understanding leader-follower outcomes. The leadership quarterly, 16(3), 373394.

Jourian, T. J. (2014). Trans forming Authentic Leadership: A Conceptual Framework. Journal of Critical Thought and Praxis, 2(2), 8. Journal, 38(7), 871-894. doi: 10.2224/sbp.2010.38.7.871

Kernis, M. H., \& Goldman, B. M. (2006). A multicomponent conceptualization of authenticity: Theory and research. Advances in experimental social psychology, 38, 283-357.

Ladebo, O. J. (2005). Relationship between citizenship behaviors and tendencies to withdraw among Nigerian agribusiness employees. Swiss journal of psychology, 64(1), 41-50.

Liden, R. C., Wayne, S. J., Kraimer, M. L., \& Sparrowe, R. T. (2003). The dual commitments of contingent workers: An examination of contingents' commitment to the agency and the organization. Journal of Organizational Behavior: The International Journal of Industrial, Occupational and Organizational Psychology and Behavior, 24(5), 609-625.

Macik-Frey, M., Quick, J. C., Shinoda, P., Mack, D. A., Gray, D. A., Keller, N., \& Cooper, C. L. (2009). Leadership from a positive health perspective. Stress and the Quality of Life-The Positive and the Negative, Charlotte NC: IAP Information Age Publishing, 95-122.

May, D. R., Chan, A. Y., Hodges, T. D., \& Avolio, B. J. (2003). Developing the moral component of authentic leadership. Organizational dynamics.

Michie, S., \& Gooty, J. (2005). Values, emotions, and authenticity: Will the real leader please stand up. The Leadership Quarterly, 16(3), 441-457.

Northouse, P. G. (1997). Leadership: Theory and research. Thousand oaks.

Penger, S., \& Černe, M. (2014). Authentic leadership, employees' job satisfaction, and work engagement: A hierarchical linear modelling approach. Economic research-Ekonomska istraživanja, 27(1), 508-526.

Pfeifer, J., \& Veiga, J. F. (1999). Putting people first for organizational success [a]. Academy of Management Executive, 13(2), 37-48.

Podsakoff, P. M., MacKenzie, S. B., Moorman, R. H., \& Fetter, R. (1990). Transformational leader behaviors and their effects on followers' trust in leader, satisfaction, and organizational citizenship behaviors. The leadership quarterly, 1(2), 107-142.

Podsakoff, P. M., \& MacKenzie, S. B. (1997). Impact of organizational citizenship behavior on organizational performance: A review and suggestion for future research. Human performance, $10(2), 133-151$. 
Podsakoff, P. M., MacKenzie, S. B., Paine, J. B., \& Bachrach, D. G. (2000). Organizational citizenship behaviors: A critical review of the theoretical and empirical literature and suggestions for future research. Journal of management, 26(3), 513-563.

Quinn, R. E., \& Spreitzer, G. M. (1997). The road to empowerment: Seven questions every leader should consider. Organizational dynamics, 26(2), 37-49.

Rego, A., Sousa, F., Marques, C., \& e Cunha, M. P. (2012). Authentic leadership promoting employees' psychological capital and creativity. Journal of business research, 65(3), 429437.

Schaufeli, W. B., \& Bakker, A. B. (2004). Job demands, job resources, and their relationship with burnout and engagement: A multi-sample study. Journal of Organizational Behavior: The International Journal of Industrial, Occupational and Organizational Psychology and Behavior, 25(3), 293-315.

Schneider, K., Renker, C., \& Maraun, M. (2005). Oribatid mite (Acari, Oribatida) feeding on ectomycorrhizal fungi. Mycorrhiza, 16(1), 67-72.

Shamir, B., \& Eilam, G. (2005). "What's your story?" A life-stories approach to authentic leadership development. The leadership quarterly, 16(3), 395-417.

Spreitzer, G. M. (1995). Psychological empowerment in the workplace: Dimensions, measurement, and validation. Academy of management Journal, 38(5), 1442-1465.

Spreitzer, G. M. (1996). Social structural characteristics of psychological empowerment. Academy of management journal, 39(2), 483-504.

Walumbwa, F. O., \& Lawler, J. J. (2003). Building effective organizations: Transformational leadership, collectivist orientation, work-related attitudes and withdrawal behaviours in three emerging economies. International journal of human resource management, 14(7), 1083-1101.

Walumbwa, F. O., Avolio, B. J., Gardner, W. L., Wernsing, T. S., \& Peterson, S. J. (2008). Authentic leadership: Development and validation of a theory-based measure. Journal of management, 34(1), 89-126.

Walumbwa, F. O., Peterson, S. J., Avolio, B. J., \& Hartnell, C. A. (2010). An investigation of the relationships among leader and follower psychological capital, service climate, and job performance. Personnel Psychology, 63(4), 937-963.

Yukl, G., Gordon, A., \& Taber, T. (2002). A hierarchical taxonomy of leadership behavior: Integrating a half century of behavior research. Journal of leadership \& organizational studies, 9(1), 15-32. 